\title{
ANALYSIS OF OPERATING CONDITIONS AND MODES INFLUENCE ON TECHNICAL STATE OF MAIN INSULATION OF HIGH-VOLTAGE BUSHINGS OF DIFFERENT DESIGN
}

The results of the analysis of the influence of operating conditions and design of high-voltage bushings on the values of dielectric loss tangent of high-voltage bushing basic insulation. For analysis a model of two-factor cross-sectional dispersion analysis, which allows to simultaneously evaluate the influence of two factors and evaluate the effect of their interaction is used. In the model used, it is assumed that the effects of changes in the levels of factors are non-additive, that is, the difference in mathematical expectations between any two levels of one factor is not the same for any levels of the other. Testing the hypothesis of the significance of the influence of factors and their interactions is performed using the Fisher criterion. This method was implemented in the form of the author' program "two-factor dispersion analysis». The results of periodic monitoring of the state of high-voltage bushings of 110, 220 and $330 \mathrm{kV}$ with different types of insulation were used as initial data. Using the model of two-factor cross-sectional dispersion analysis, it was found that the aging intensity of the main insulation of bushings is influenced by both the operating conditions and the design features of the bushings. Maximum permissible values of diagnostic indicators of high-voltage bushings should be normalized taking into account such factors as nominal voltage, type of protection and type of insulation, load of bushings and the composition of consumers. Since, based on the analysis performed, it was established that these factors have a significant impact on the values of diagnostic indicators of insulation of bushings. According to the results of the analysis performed, it was established that such factors as the type of bushing and phase do not have a significant effect on the change in the values of diagnostic indicators of high-voltage bushings, and, therefore, they can be ignored when determining the maximum permissible values of the indicators. References 24 , tables 7, figures 14.

Key words: high-voltage bushing, insulation, two-factor cross-sectional dispersion analysis, insulation indicators, dielectric loss tangent.

Метою статті є аналіз впливу умов, режимів експлуатації і конструкції високовольтних вводів на значення тангенса кута діелектричних втрат основної ізоляції конденсаторного типу високовольтних вводів. Для аналізу використовується модель двохфакторного перехресного дисперсійного аналізу, яка дозволяє одночасно виконати оцінку впливу двох чинників і оцінити ефект їх взаємодії. У використовуваної моделі передбачається неадитивність ефектів зміни рівнів факторів, тобто різниця математичних очікувань між будь-якими двома рівнями одного фактора не однакова при будь-яких рівнях іншого. Перевірка гіпотези про значущість впливу факторів $і$ їх взаємодій виконується за допомогою критерію Фішера. Результати. Даний метод був реалізований у вигляді авторськой програми «двохфакторний дисперсійний аналіз». В якості вихідних даних були використані результати періодичного контролю стану високовольтних вводів напругою 110, 220 i 330 кВ з ізоляцією різного типу. Використовуючи модель двохфакторного перехресного дисперсійного аналізу, встановлено, щцо на інтенсивність старіння основної ізоляцї̈ вводів впливають як умови експлуатацї, так і особливості конструктивного виконання вводів. Нові положення, в порівнянні з відомими ріменнями, полягають у тому, щи гранично допустимі значення діагностичних ознак високовольтних вводів слід нормувати з урахуванням таких факторів, як номінальна напруга, тип захисту $і$ тип ізоляцї, завантаження вводів $і$ склад споживачів. Отримані результати можуть бути алгоритмічно реалізовані у вигляді окремого модуля інформаційно-аналітичної системи (ІАС) для діагностики стану високовольтного маслонаповненного обладнання. Бібл. 24, табл. 7, рис. 14.

Ключові слова: високовольтний ввід, ізоляція, двохфакторний перехресний дисперсійний аналіз, показники ізоляції, тангенс кута діелектричних втрат.

Целью статьи является анализ влияния условий, режимов эксплуатации и конструкции высоковольтных вводов на значения тангенса угла диэлектрических потерь основной изоляции конденсаторного типа высоковольтных вводов. Для анализа используется модель двухфакторного перекрестного дисперсионного анализа, которая позволяет одновременно выполнить оценку влияния двух факторов и оценить эффект их взаимодействия. В используемой модели предполагается неаддитивность эффектов изменения уровней факторов, т.е. разность математических ожиданий между любыми двумя уровнями одного фактора не одинакова при любых уровнях другого. Проверка гипотезы о значимости влияния факторов и их взаимодействий выполняется с помощью критерия Фишера. Данный метод был реализован в виде авторской программы «двухфакторный дисперсионный анализ». В качестве исходных данных были использованы результаты периодического контроля состояния высоковольтных вводов напряэением 110, 220 и 330 кВ с изоляцией разного типа. Используя модель двухфакторного перекрестного дисперсионного анализа, установлено, что на интенсивность старения основной изоляции вводов оказывают влияние как условия эксплуатации, так и особенности конструктивного исполнения вводов. Новые положения, по сравнению с известными решениями, состоят в том, что предельно допустимые значения диагностических признаков высоковольтных вводов следует нормировать с учетом таких факторов, как номинальное напряэение, тип защиты и тип изоляции, загрузка вводов и состав потребителей. Полученные результаты могут быть алгоритмически реализованы в виде отдельного модуля информационно-аналитической системы (ИАС) для диагностики состояния высоковольтного маслонаполненного оборудования. Библ. 24, табл. 7, рис. 14.

Ключевые слова: высоковольтный ввод, изоляция, двухфакторный перекрестный дисперсионный анализ, показатели изоляции, тангенс угла диэлектрических потерь.

Problem definition. The decision on the possible state of high-voltage bushings, when conducting periodic

tests, is made by comparing the measured values of the (C) O.V. Shutenko, A.A. Zagaynova, G.N. Serdyukova 
insulation indicators with their maximum allowable values. It is obvious that the more adequate the maximum permissible values of bushing indicators will reflect the conditions of actual operation of bushings, the higher will be the reliability of decisions made with their use. Currently, according to [1], the maximum permissible values of the main insulation parameters of bushings (the values of the dielectric loss tangents of the main insulation and insulation of the measuring capacitor) are normalized only taking into account the nominal voltage and type of insulation. However, the study of the distribution laws of the insulation indicators of the bushings, performed in [2], showed that even for bushings of the same voltage class with the same type of insulation, there is a shift in the mathematical expectations of the distribution densities of the indicators. This is due to the influence of operational factors, the consideration of which is not regulated in [1]. The presence of such a shift indicates that the optimal maximum permissible values of indicators obtained for arrays of indicators with different parameters of the laws of distributions will differ significantly. And this means that when determining the maximum permissible values, it is necessary to take into account a larger number of factors than is regulated in [1]. In this regard, the analysis of factors influencing the values of diagnostic indicators of high-voltage bushings during long-term operation is an actual and practically important task.

Analysis of major achievements and literature. Currently, open literature contains a significant number of publications devoted to improving the operational reliability of high-voltage bushings. For example, in [3-7] a detailed analysis of the main causes of damage and the most characteristic defects in high-voltage bushings was performed. It is shown that for bushings with different types of insulation there are different characteristic defects. According to international and national Standards $[1,8,9]$, when conducting periodic tests of the state of insulation of high-voltage bushings, the values of the following indicators are monitored: dielectric loss angle tangent of main insulation $\left(\operatorname{tg} \delta_{1}\right)$, main insulation capacitance $\left(C_{1}\right)$, dielectric loss angle tangent of measuring capacitor $\left(\operatorname{tg} \delta_{2}\right)$, capacitance of measuring capacitor $\left(C_{2}\right)$, and the insulation resistance of the output to measure $(R)$. Examples of damage of high-voltage bushings with different types of insulation are given in $[10,11]$. It is shown and justified that the most informative indicator for both paper-oil and RIP-insulated (resin impregnated paper) bushings is the dielectric loss tangent of the main insulation. In this case, the monitoring of this indicator should be carried out using continuous monitoring systems. A sufficient number of publications [12-14] are devoted to the analysis of the effect of the most characteristic defects of high-voltage bushings on the values of the tangent of the dielectric loss angle of the main insulation. At the same time, the issues of evaluating factors affecting the values of $\operatorname{tg} \delta_{1}$ of serviceable highvoltage bushings during long-term operation are not sufficiently analyzed. So in [15] the results of the dispersion analysis of operational factors on the values of bushing indicators are given. It has been established that the type of bushing and the duration of operation have a significant impact on the values of the indicators. However, the above studies were performed on a limited amount of sample data and did not take into account the effects of loading the bushings. The latter circumstance was the basis for the performance of these studies.

The goal of the paper is analysis of the influence of conditions, modes of operation and design on the technical state of the main insulation of high-voltage bushings based on the results of preventive measurements of the dielectric loss tangent at frequency of $50 \mathrm{~Hz}$

Research methods. Currently, several models of dispersion analysis have been developed and are widely used for factor analysis $[16,17]$. It should be noted that the choice of a particular model of analysis requires a sufficiently deep justification. For example, in [18], a single-factor model of dispersion analysis was used to form statistically homogeneous arrays of gas concentrations. This approach allows to perform a dispersion decomposition with an unequal number of measurements in cells, but it requires strict fixation of all factors, except for the variable factor, at strictly defined levels, which is not always possible when working with operational data. The use of models based on Latin squares [19] allows to simultaneously check the influence of several factors, but does not allow us to estimate the effects of interaction between them. In such conditions, the most optimal, according to the authors, is the use of a two-factor cross-sectional analysis model [15, 20, 21], which allows to simultaneously evaluate the influence of two factors and evaluate the effect of their interaction.

Taking into account the alleged non-additive effects of changing levels of factors (that is, the difference in mathematical expectations between any two levels of one factor is not the same for any levels of another), the model of the components of the dispersion can be represented as [22]:

$$
y_{i j r}=\mu+\rho_{i}+\gamma_{j}+(\rho \gamma)_{i j}+\varepsilon_{i j r},
$$

where $y_{i j r}$ is the value of the insulation indicator; $\mu$ is the general average; $\rho_{i}$ is the average deviation relative to $\mu$ for the $i$-th level of the first factor; $\gamma_{j}$ is the average deviation relative to $\mu$ for the $j$-th level of the second factor; $(\rho \gamma)_{i j}$ is the component that characterizes the interaction between factors; $\varepsilon_{i j r}$ is the residual random variable; $i$ is the level of the first factor; $j$ is the level of the second factor; the order of occurrence of one of $m_{i j}$ observations for combining the $i$-th level of the first with the $j$-th level of the second factor.

It is known [22] that the expression for the total sum of squares of deviations from the common average for model (1) is:

$$
\begin{aligned}
& \sum_{i=1}^{n} \sum_{j=1}^{k} \sum_{r=1}^{m}\left(\bar{y}_{i j}-\bar{y}\right)^{2}=k \cdot m \cdot \sum_{i=1}^{n}\left(\bar{y}_{i}-\bar{y}\right)^{2}+ \\
& +n \cdot m \cdot \sum_{j=1}^{k}\left(\bar{y}_{j}-\bar{y}\right)^{2}+m \cdot \sum_{i=1}^{n} \sum_{j=1}^{k}\left(\bar{y}_{i j}-\bar{y}_{i}-\bar{y}_{j}+\bar{y}^{2}+\right. \\
& +\sum_{i=1}^{n} \sum_{j=1}^{k} \sum_{r=1}^{m}\left(\bar{y}_{i j r}-\bar{y}_{i j}\right)^{2}
\end{aligned}
$$


or

$$
Q_{t o t}=Q_{A}+Q_{B}+Q_{A B}+Q_{\varepsilon},
$$

where $Q_{\text {tot }}=\sum_{i=1}^{n} \sum_{j=1}^{k} \sum_{r=1}^{m}\left(\bar{y}_{i j}-\bar{y}\right)^{2}$ is the total sum of squares of deviations from total average; $Q_{A}=k \cdot m \cdot \sum_{i=1}^{n}\left(\bar{y}_{i}-\bar{y}\right)^{2}$ is the sum of squares of deviations, which characterizes the scattering of the averages in rows relative to the total average; $Q_{B}=n \cdot m \cdot \sum_{j=1}^{k}\left(\bar{y}_{j}-\bar{y}\right)^{2}$ is the sum of squares of deviations from the total average between the columns, which characterizes the scattering of the averages by the columns; $Q_{A B}=m \cdot \sum_{i=1}^{n} \sum_{j=1}^{k}\left(\bar{y}_{i j}-\bar{y}_{i}-\bar{y}_{j}+\bar{y}\right)^{2}$ is the sum of squares of deviations characterizing the effect of mutual influence; $Q_{\varepsilon}=\sum_{i=1}^{n} \sum_{j=1}^{k} \sum_{r=1}^{m}\left(\bar{y}_{i j r}-\bar{y}_{i j}\right)^{2}$ is the sum of squares of deviations within the series, which characterizes the scattering of individual observations in a series relative to the average of the series, due to the influence of random variables only.

Checking the hypothesis about the significance of the influence of factors and their interactions was carried out using the Fisher criterion. For this, we first found the estimates of the mean squares.

General:

$$
\bar{Q}_{\text {tot }}^{2}=\frac{Q_{\text {tot }}}{n \cdot k \cdot m-1}=\sigma_{\varepsilon}^{2}+\sigma_{A}^{2}+\sigma_{B}^{2}+\sigma_{A B}^{2} ;
$$

between rows:

$$
\bar{Q}_{A}^{2}=\frac{Q_{A}}{n-1}=\sigma_{\varepsilon}^{2}+k \cdot m \cdot \sigma_{A}^{2}+m \cdot \sigma_{A B}^{2}
$$

between columns:

$$
\bar{Q}_{B}^{2}=\frac{Q_{B}}{k-1}=\sigma_{\varepsilon}^{2}+n \cdot m \cdot \sigma_{B}^{2}+m \cdot \sigma_{A B}^{2} ;
$$

interactions:

$$
\bar{Q}_{A B}^{2}=\frac{Q_{A B}}{(n-1) \cdot(k-1)}=\sigma_{\varepsilon}^{2}+m \cdot \sigma_{A B}^{2}
$$

residual:

$$
\bar{Q}_{\varepsilon}^{2}=\frac{Q_{\varepsilon}}{n \cdot k \cdot(m-1)}=\sigma_{\varepsilon}^{2} .
$$

The values of the $F$-criteria were calculated as the ratio of the respective mean squares to the residual mean square:

$$
F_{A}=\frac{\bar{Q}_{A}^{2}}{\bar{Q}_{\varepsilon}^{2}}, \quad F_{B}=\frac{\bar{Q}_{B}^{2}}{\bar{Q}_{\varepsilon}^{2}}, \quad F_{A B}=\frac{\bar{Q}_{A B}^{2}}{\bar{Q}_{\varepsilon}^{2}} .
$$

The hypothesis about the absence of the influence of a factor or interaction effect was not rejected if the calculated $F$-criterion value did not exceed the critical value, with the corresponding values of the number of degrees of freedom and significance level $\alpha=0.05$. This method was implemented in the form of the authors' program «DDA» (Two-Factor Dispersion Analysis), described in [23].

As initial data, the results of periodic monitoring of the state of high-voltage bushings of 110,220 and $330 \mathrm{kV}$ with different types of insulation, which are operated in Kharkiv, Poltava and Lugansk regions of Ukraine, were used. As a response, the values of the dielectric loss tangent of the main insulation of high-voltage bushings were analyzed.

The results of numerical simulation. Below are the results of checking the influence of various factors.

Analysis of the significance of the differences of $\operatorname{tg} \delta_{1}$ values of high-voltage bushings, which are operated with different values of the load current. The operating temperature of the insulation is one of the main factors determining the intensity of its aging [24]. In [20] it was shown that the aging rate of transformer oils largely depends on the load on the transformers. In high-voltage bushings, the operating temperature is largely determined by both the operating current (load current) and the ambient temperature. For leveling the influence of ambient temperature and other factors, when assessing the impact of load of the bushings, we used the results of periodic tests for high-voltage bushings of $110 \mathrm{kV}$ of sealed design with paper-oil insulation of the type ГБМТ$110 / 630 \mathrm{y} 1$, which were put into operation in the 80s years and operate in the Kharkiv region. The sample size was 144 values: 3 columns, the volumes of sample values in the cells is 6 , the number of cells is 24 . The first factor was considered to be transformer load $(k z)$, for which three levels of variation were allocated: up to $25 \%$, $25-50 \%$ and over $50 \%$ As the second factor, the influence of the duration of operation was analyzed. The time interval from 0 (time of commissioning) to 21 years was considered. The test results, by the factor of operation duration (in rows), were divided into 7 levels, with a step of 3 years. The dynamics of change of $\operatorname{tg} \delta_{1}$ of the main insulation of high-voltage bushings with different values of the load factor $k z$ during operation is shown in Fig. 1.

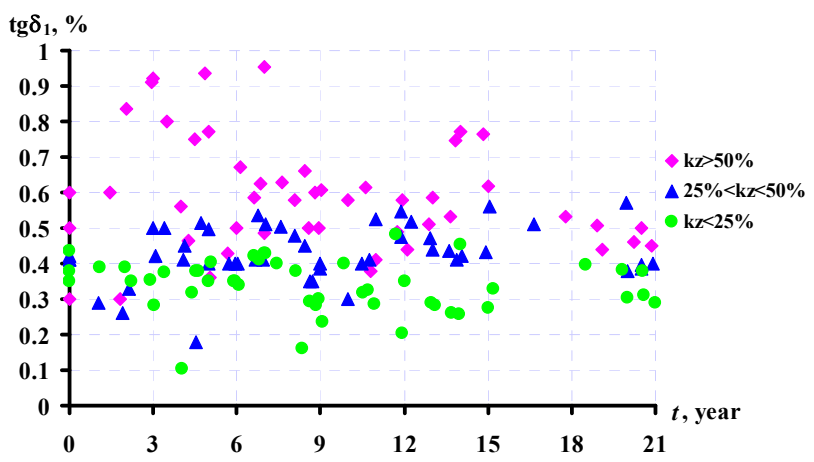

Fig. 1. Dynamics of change of $\operatorname{tg} \delta_{1}$ of the main insulation of high-voltage bushings with different values of the load factor $k z$ during operation

The main hypothesis was the assumption that there are no significant effects of these factors. The distribution 
of the average values of the tangent of the dielectric loss angle of the main insulation of high-voltage bushings, according to the levels of the influencing factors, is shown in Fig. 2. The results of the dispersion decomposition are given in Table 1. As can be seen from Table 1, the hypothesis of the absence of the influence of the operating time on the tangent of the dielectric loss angle of the main insulation of the bushings was rejected $\left(F_{A}>F_{c r}\right)$. This means that the values of $\operatorname{tg} \delta_{1}$ change over the duration of operation. The hypothesis about the absence of the influence of the load current on the values of the tangent of the dielectric loss angle of the insulation of the bushings was also rejected $\left(F_{B}>F_{c r}\right)$. This indicates the presence of significant differences in the values of $\operatorname{tg} \delta_{1}$ of serviceable high-voltage bushings, which are operated with different load values.

Quite interesting is the fact that according to the results of the analysis, the mutual influence of the duration of operation and load on the values of the tangent of the dielectric loss angle $\left(F_{A B}>F_{c r}\right)$ was established. This suggests that the effects of changing levels of factors are non-additive, i.e. the effect of a change in the level of influence of one factor leads to a change in the effect of the level of the impact of another. In other words, the aging process is cumulative, i.e. similar $\operatorname{tg} \delta_{1}$ values can be obtained with high loads over a relatively short period of operation, or with lower loads, but over a longer period of operation.

Table 1

The results of checking the influence of load of bushings and duration of operation on the values of $\operatorname{tg} \delta_{1}$

\begin{tabular}{|c|c|c|c|c|c|c|}
\hline \multirow{2}{*}{$\begin{array}{c}\text { Sums of dispersion } \\
\text { decomposition }\end{array}$} & \multicolumn{2}{|c|}{$\begin{array}{c}\text { Number of } \\
\text { degrees of } \\
\text { freedom }\end{array}$} & & \multicolumn{3}{|c|}{$F$-criterion } \\
\cline { 5 - 7 } & & & calculated & critical \\
\hline$Q_{\text {tot. }}$ & 4.04 & $v_{\text {tot. }}$ & 143 & & & \\
\hline$Q_{\mathrm{A}}$ & 0.20 & $v_{\mathrm{A}}$ & 7 & $F_{A}$ & 3.090 & 2.408 \\
\hline$Q_{\mathrm{B}}$ & 1.54 & $v_{\mathrm{B}}$ & 2 & $F_{B}$ & 81.92 & 3.804 \\
\hline$Q_{\mathrm{AB}}$ & 0.45 & $v_{\mathrm{AB}}$ & 14 & $F_{A B}$ & 3.416 & 1.981 \\
\hline$Q_{\varepsilon}$ & 1.13 & $v_{\varepsilon}$ & 120 & - & - & - \\
\hline
\end{tabular}

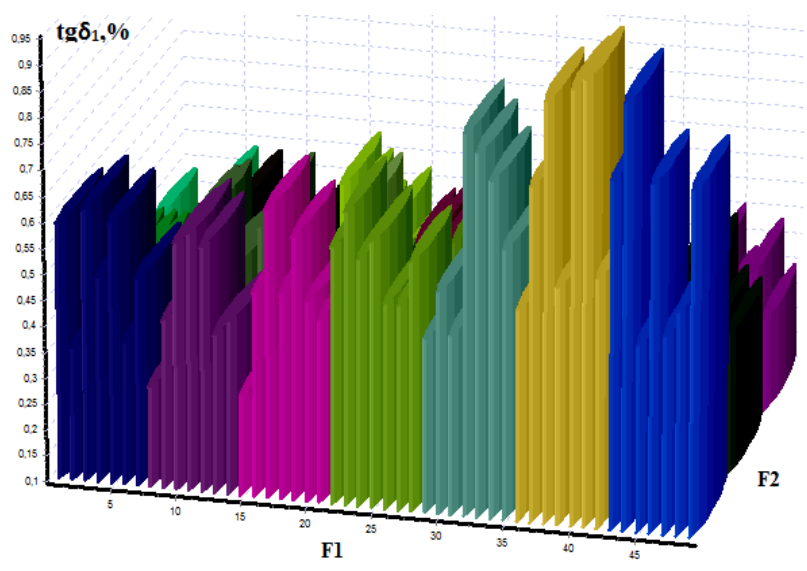

Fig. 2. The distribution of the average values of $\operatorname{tg} \delta_{1}$ of main insulation depending on the duration of operation (factor F1) and the load current (factor F2) of high-voltage bushings. The significant influence of the load factor was also confirmed for the bushings with voltage class of 220 and $330 \mathrm{kV}$ with different types of insulation
Analysis of the significance of the differences of $\operatorname{tg} \delta_{1}$ values in serviceable high-voltage bushings, with different types of insulation. The normative document acting in Ukraine [1] regulates the values of diagnostic indicators depending on the type of insulation of bushings (oil-paper, oil barrier, paper-bakelite insulation of the bushing with mastic filling, solid insulation of the bushing with oil filling, etc.).

To check the expected impact of the bushing insulation type on the values of diagnostic indicators, a two-factor dispersion analysis of the tangent of the dielectric loss angle of the main insulation for paper-oilinsulated bushings of type ГMTA $110 \mathrm{kV}$ and bushings of ГTTA type $110 \mathrm{kV}$ (the frame is wired with cable crepe paper and impregnated with epoxy compound) was performed.

The analyzed bushings were commissioned in the mid-80s and operate in Kharkiv region. The average load of these bushings was $25-50 \%$ of the rated current value. As in the previous case, the influence of the operating time was analyzed as the second factor, a time interval from 0 (commissioning time) to 24 years was considered. The test results, by the factor of operation duration (in rows), were divided into 6 levels, with a step of 4 years. The size of the analyzed sample was 156 values: 6 rows, 2 columns, 13 values per cell. The dynamics of $\operatorname{tg} \delta_{1}$ change during operation for bushings with different types of insulation is shown in Fig. 3.

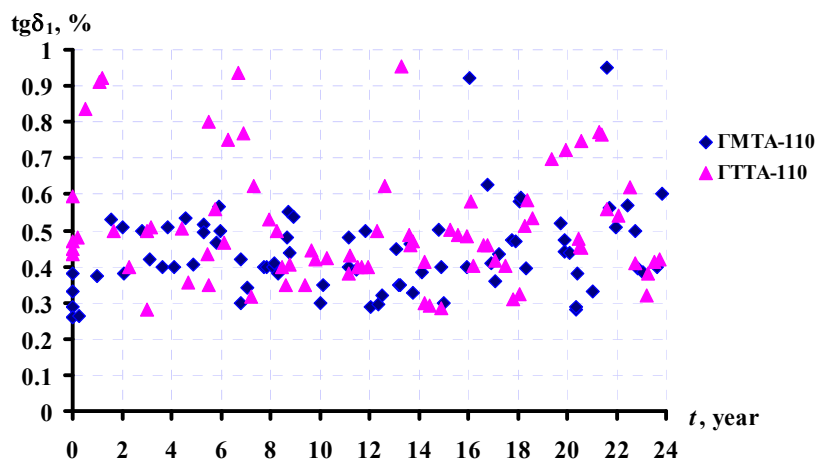

Fig. 3. Dynamics of change of $\operatorname{tg} \delta_{1}$ during operation for bushings with different types of insulation

The results of the dispersion decomposition are given in Table 2. The main hypothesis was the assumption that there are no significant effects of these factors. The distribution of the average values of the tangent of the dielectric loss angle of the main insulation of high-voltage bushings by the levels of the influencing factors is shown in Fig. 4. As can be seen from Table 2, the calculated value of the $F_{A}$ criterion does not exceed the critical value; therefore, for the analyzed data, the change in $\operatorname{tg} \delta_{1}$ values during operation is not statistically significant. At the same time, there is a significant difference in the values of $\operatorname{tg} \delta_{1}$ in bushings with different types of insulation $\left(F_{B}>F_{c r}\right)$. At the same time, dispersion analysis did not reveal significant differences in the values of $\operatorname{tg} \delta_{1}$, due to the mutual influence of the duration of operation and the type of insulation. 
Table 2 of various types $\left(F_{B}<F_{c r}\right)$. In addition, differences in the

The results of checking the influence of insulation type of bushings and duration of operation on the values of $\operatorname{tg} \delta_{1}$

\begin{tabular}{|c|c|c|c|c|c|c|}
\hline \multirow{2}{*}{\multicolumn{2}{|c|}{$\begin{array}{l}\text { Sums of dispersion } \\
\text { decomposition }\end{array}$}} & \multirow{2}{*}{\multicolumn{2}{|c|}{$\begin{array}{l}\text { Number of } \\
\text { degrees of } \\
\text { freedom }\end{array}$}} & \multicolumn{3}{|c|}{$F$-criterion } \\
\hline & & & & \multirow[t]{2}{*}{$F$} & \multirow[t]{2}{*}{ calculated } & \multirow{2}{*}{ critical } \\
\hline$Q_{\text {tot. }}$ & 3.31 & $v_{\text {tot. }}$ & 155 & & & \\
\hline$Q_{\mathrm{A}}$ & 0.13 & $v_{\mathrm{A}}$ & 5 & $F_{\mathrm{A}}$ & 1.34 & 2.56 \\
\hline$Q_{\mathrm{B}}$ & 0.17 & $v_{\mathrm{B}}$ & 1 & $F_{\mathrm{B}}$ & 8.97 & 5.02 \\
\hline$Q_{\mathrm{AB}}$ & 0.16 & $v_{\mathrm{AB}}$ & 5 & $F_{\mathrm{AB}}$ & 1.65 & 2.56 \\
\hline$Q_{\varepsilon}$ & 2.84 & $v_{\varepsilon}$ & 144 & - & - & - \\
\hline
\end{tabular}

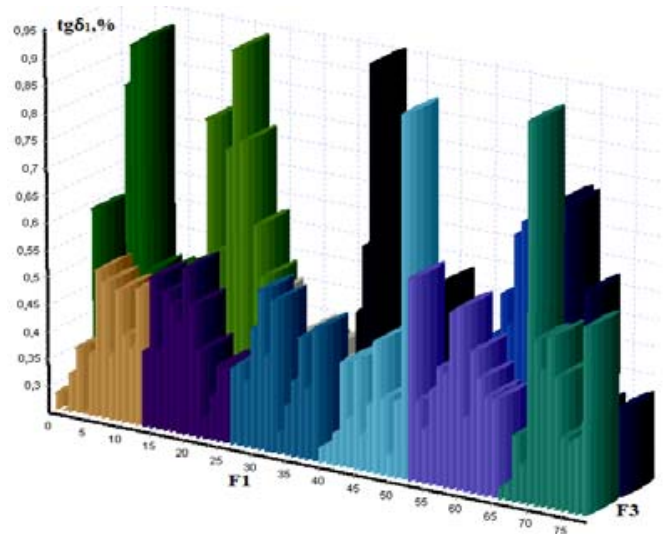

Fig. 4. The distribution of the average values of $\operatorname{tg} \delta_{1}$ of main insulation of bushings depending on the duration of operation (factor F1) and the type of insulation (factor F3)

Analysis of the significance of differences of $\operatorname{tg} \delta_{1}$ values in serviceable high-voltage bushings of various types. Since the analysis revealed a significant effect of the insulation type of high-voltage bushings on the values of $\operatorname{tg} \delta_{1}$, it would be logical to check whether the type of bushings has a similar effect.

To test the hypothesis of the type of bushing influence, we analyzed the values of the tangent of dielectric loss angle for hermetic bushings with paper-oil insulation of two types: ГМТА and ГБМТУ.

As the second factor, the effect of the lifetime of the bushings was analyzed. As in the previous case, the values of $\operatorname{tg} \delta_{1}$ were analyzed in the operation interval up to 24 years, with a 4 -year step.

Analyzed bushings are operated in Kharkiv region, and were put into operation in the $80 \mathrm{~s}$. The average load of high-voltage bushings exceeded $50 \%$. The total sample size was 120 values: 6 rows, 2 columns, 10 values per cell.

Fig. 5 shows the dependence of $\operatorname{tg} \delta_{1}$ on the duration of operation for bushings of various types.

The main hypothesis was the assumption that there are no significant effects of these factors. The distribution of the average values of the tangent of the dielectric loss angle of the main insulation of high-voltage bushings by the levels of the influencing factors is shown in Fig. 6.

The results of the dispersion decomposition are given in Table 3.

As can be seen from Table 3, for the data analyzed, the change in $\operatorname{tg} \delta_{1}$ values over time is not statistically significant $\left(F_{A}<F_{c r}\right)$. There were also no significant differences in the values of $\operatorname{tg} \delta_{1}$ for high-voltage bushings values of $\operatorname{tg} \delta_{1}$, which are due to the mutual influence of the types of bushings and the duration of operation, are not statistically significant $\left(F_{A B}<F_{c r}\right)$.

It should be noted that similar results were obtained for bushings of the type ГТБТУ-110, ГТТБ-110 and ГTTA-110.

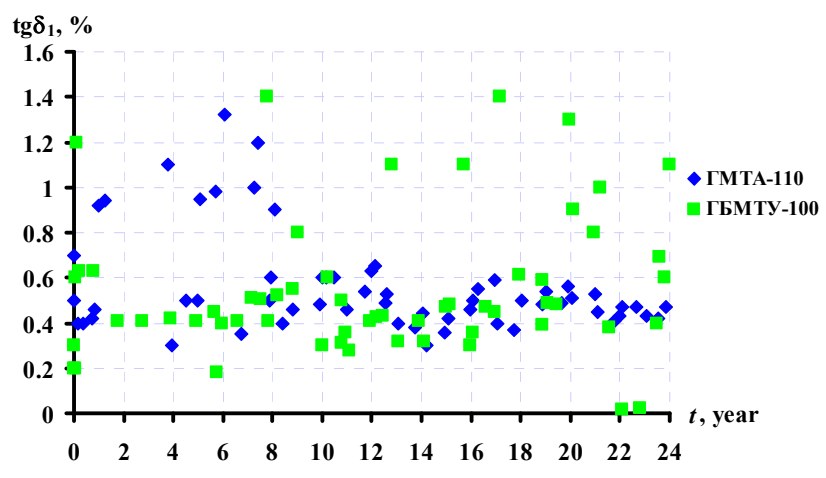

Fig. 5. Dynamics of change of $\operatorname{tg} \delta_{1}$ on the duration of operation for bushings of different types

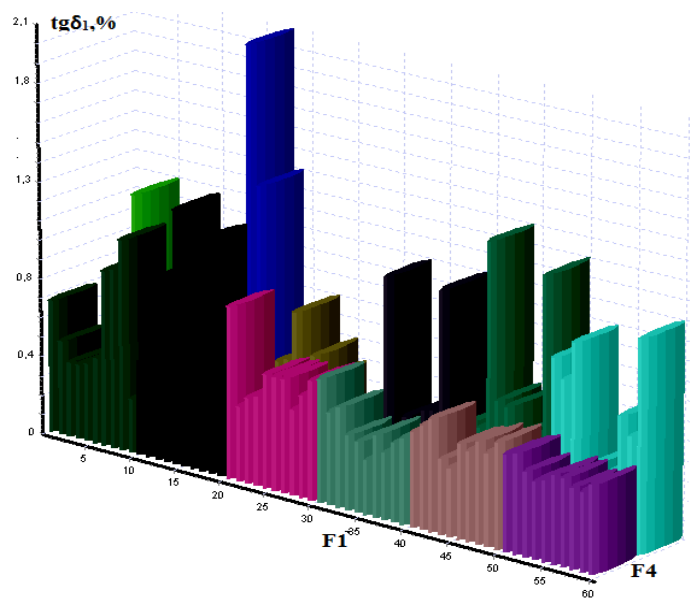

Fig. 6. The distribution of average values of $\operatorname{tg} \delta_{1}$ of main insulation depending on the duration of operation (factor F1) and type (factor F4) of high-voltage bushings

Table 3

The results of checking the influence of duration of operation and bushing type on values of $\operatorname{tg} \delta_{1}$

\begin{tabular}{|c|c|c|c|c|c|c|}
\hline \multirow{2}{*}{$\begin{array}{c}\text { Sums of dispersion } \\
\text { decomposition }\end{array}$} & \multicolumn{2}{|c|}{$\begin{array}{c}\text { Number of } \\
\text { degrees of } \\
\text { freedom }\end{array}$} & \multicolumn{3}{|c|}{$F$-criterion } \\
\cline { 1 - 1 } \cline { 7 - 7 }$Q_{\text {tot. }}$ & 10.89 & $v_{\text {tot. }}$ & 119 & & calculated & critical \\
\hline$Q_{\mathrm{A}}$ & 0.76 & $v_{\mathrm{A}}$ & 5 & $F_{\mathrm{A}}$ & 1.715 & 2.69 \\
\hline$Q_{\mathrm{B}}$ & 0.002 & $v_{\mathrm{B}}$ & 1 & $F_{\mathrm{B}}$ & 0.023 & 5.17 \\
\hline$Q_{\mathrm{AB}}$ & 0.43 & $v_{\mathrm{AB}}$ & 5 & $F_{\mathrm{AB}}$ & 0.962 & 2.69 \\
\hline$Q_{\varepsilon}$ & 9.68 & $v_{\varepsilon}$ & 108 & - & - & - \\
\hline
\end{tabular}

Analysis of the significance of differences of $\operatorname{tg} \delta_{1}$ values in serviceable high-voltage bushings with different types of bushing protection. In addition to bushing load that determine the operating temperature of the insulation, the content of chemically aggressive media (moisture, atmospheric oxygen) has a significant effect on the intensity of the insulation aging processes. Obviously, 
the degree of influence of chemically aggressive media on the aging intensity of the insulation will largely depend on the type of protection of the insulation of the bushings (hermetic or non-hermetic). To assess the impact of the type of protection, a dispersion analysis of the values of the tangent of the dielectric loss angle of the main insulation for the sealed-type bushings of the ГБМТ type and the non-hermetic bushings of the БMT type with rated voltage of $110 \mathrm{kV}$ was carried out. These bushings were commissioned in the late 70 s and operate in Kharkiv region. The average value of load currents on the analyzed period of time (up to 20 years) exceeded $50 \%$ of the value of the rated current of the bushings. The sample size was 200 values: 10 rows, 2 columns, 10 measurements per cell. The dynamics of changes in the dielectric loss tangent of high-voltage bushings of nonhermetic and hermetic design during operation is shown in Fig. 7.

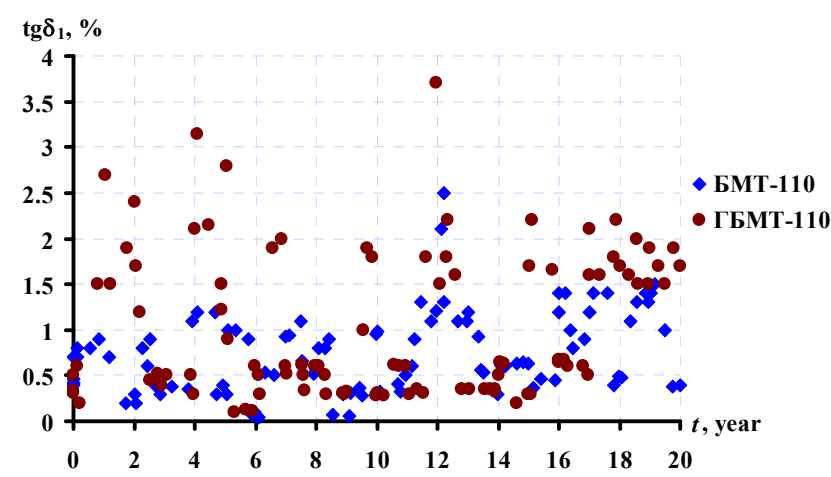

Fig. 7. Dynamics of changes in the dielectric loss tangent of high-voltage bushings of unsealed and hermetic designs during operation

The distribution of the average values of the tangent of the dielectric loss angle of the main insulation of highvoltage bushings by the levels of the influencing factors is shown in Fig. 8. The main hypothesis was the assumption that there are no significant effects of these factors. The results of the dispersion decomposition are given in Table 4. As can be seen from Table 4, for a given sample, the calculated value of the $F_{A}$ criterion exceeds the critical value, and, therefore, changes in the $\operatorname{tg} \delta_{1}$ values over time are statistically significant. In addition, significant differences in the values of $\operatorname{tg} \delta_{1}$ for bushings of the hermetic and unpressurized design $\left(F_{B}>F_{c r}\right)$ were revealed. At the same time, unlike bushings with different values of load factor, for bushings with different types of protection there are no significant differences in the values of $\operatorname{tg} \delta_{1}$, which are due to the mutual influence of the type of bushing protection and the duration of operation $\left(F_{A B}<F_{c r}\right)$.

Analysis of the significance of the differences of $\operatorname{tg} \delta_{1}$ values in serviceable high-voltage bushings installed on different phases of transformers. As a rule, electrical networks operate in a symmetric mode, i.e. the values of the load current in different phases should coincide and, therefore, the values of the diagnostic indicators in serviceable, normally operating bushings should not differ significantly. At the same time, if a defect occurs in one of the bushings, the values of diagnostic indicators differ, which allows detecting a defect. This is the basis of the nonequilibriumcompensation method for continuous monitoring of the insulation state of the bushings [24].

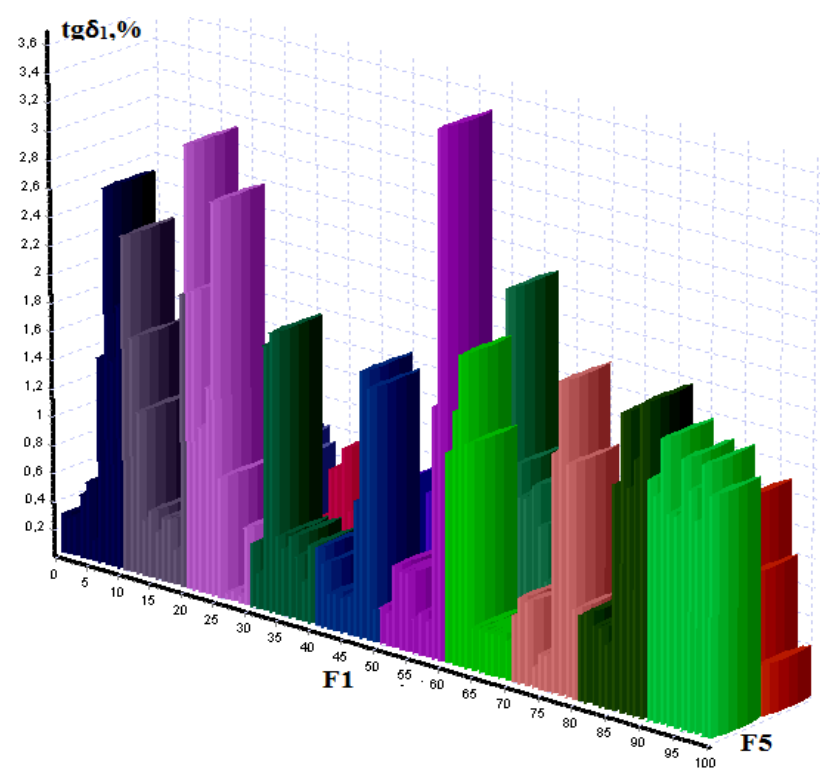

Fig. 8. The distribution of average values of $\operatorname{tg} \delta_{1}$ of basic insulation depending on the duration of operation (factor F1) and type of protection (factor F5) of high-voltage bushings

Table 4

The results of checking the influence of the duration of operation and the type of protection of bushings on the values of $\operatorname{tg} \delta_{1}$

\begin{tabular}{|c|c|c|c|c|c|c|}
\hline \multirow{2}{*}{$\begin{array}{c}\text { Sums of dispersion } \\
\text { decomposition }\end{array}$} & \multicolumn{2}{|c|}{$\begin{array}{c}\text { Number of } \\
\text { degrees of } \\
\text { freedom }\end{array}$} & & \multicolumn{3}{|c|}{$F$-criterion } \\
\cline { 5 - 7 } & & & & & & \\
calculated & critical \\
\hline$Q_{\text {tot. }}$ & 86.3 & $v_{\text {tot. }}$ & 199 & & & \\
\hline$Q_{\mathrm{A}}$ & 9.42 & $v_{\mathrm{A}}$ & 9 & $F_{\mathrm{A}}$ & 2.706 & 2.11 \\
\hline$Q_{\mathrm{B}}$ & 4.16 & $v_{\mathrm{B}}$ & 1 & $F_{\mathrm{B}}$ & 10.77 & 5.02 \\
\hline$Q_{\mathrm{AB}}$ & 3.19 & $v_{\mathrm{AB}}$ & 9 & $F_{\mathrm{AB}}$ & 0.917 & 2.11 \\
\hline$Q_{\varepsilon}$ & 69.5 & $v_{\varepsilon}$ & 180 & - & - & - \\
\hline
\end{tabular}

To check the hypothesis about the effect of the phase on the values of the indicators, the values of $\operatorname{tg} \delta_{1}$ of highvoltage bushings with voltage of $110 \mathrm{kV}$ of the ГМТA type were analyzed. These bushings were commissioned in the early 90s. The sample size was 150 values: 10 rows, 3 columns, 5 measurements per cell. The division step by factor of the duration of operation was 2 years.

The dynamics of $\operatorname{tg} \delta_{1}$ change during the operation of high-voltage bushings of a hermetic design, installed on different phases of transformers, is shown in Fig. 9.

The distribution of the average values of the tangent of the dielectric loss angle of the main insulation of highvoltage bushings by the levels of the influencing factors is shown in Fig. 10.

The main hypothesis was the assumption that there are no significant effects of these factors. 


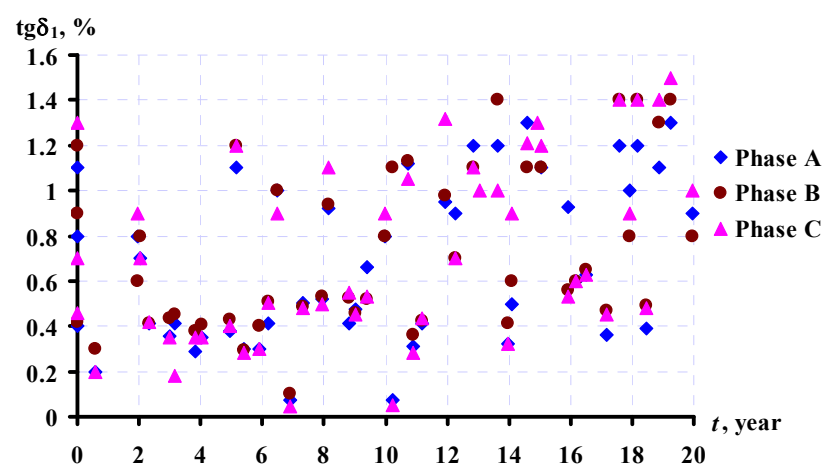

Fig. 9. Dynamics of change of $\operatorname{tg} \delta_{1}$ during the operation of high-voltage bushings of sealed design, installed on different transformer phases

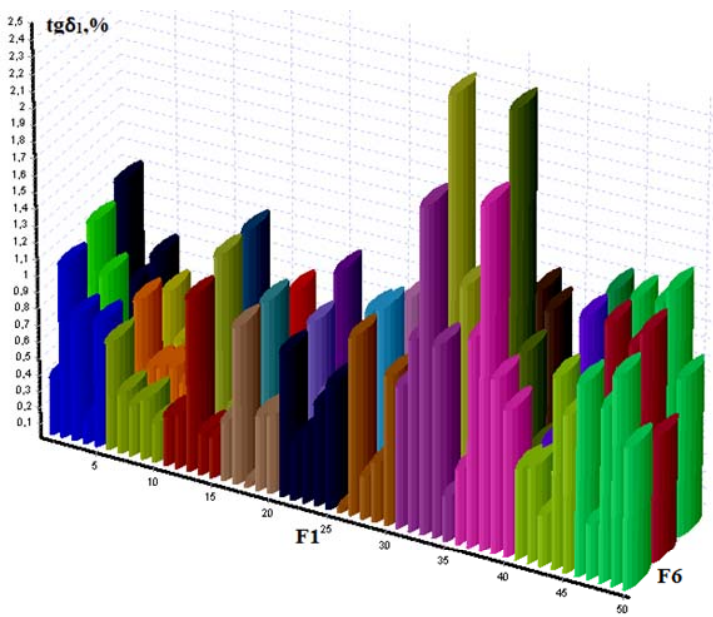

Fig. 10. The distribution of the average values of $\operatorname{tg} \delta_{1}$ of main insulation depending on the duration of operation (factor F1) and phase (factor F6) of high-voltage bushings

The results of the dispersion decomposition are given in Table 5. As can be seen from Table 5, the calculated value of the $F_{A}$ criterion exceeds the critical value, and therefore, changes in the $\operatorname{tg} \delta_{1}$ values over time for a given sample are statistically significant. At the same time, there are no significant differences in the values of $\operatorname{tg} \delta_{1}$ for high-voltage bushings installed at different phases of transformers $\left(F_{B}<F_{c r}\right)$. There are also no significant differences in the values of $\operatorname{tg} \delta_{1}$, due to the mutual influence of the bushing phase and the duration of operation $\left(F_{A B}<F_{c r}\right)$.

Table 5

The results of checking the influence of the duration of operation and the phase number of the bushings on the values of $\operatorname{tg} \delta_{1}$

\begin{tabular}{|c|c|c|c|c|c|c|}
\hline \multirow{2}{*}{$\begin{array}{c}\text { Sums of dispersion } \\
\text { decomposition }\end{array}$} & \multicolumn{2}{|c|}{$\begin{array}{c}\text { Number of } \\
\text { degrees of } \\
\text { freedom }\end{array}$} & & \multicolumn{3}{|c|}{$F$-criterion } \\
\cline { 5 - 7 } & & & calculated & critical \\
\hline$Q_{\text {tot. }}$ & 29.6 & $v_{\text {tot. }}$ & 149 & & & \\
\hline$Q_{\mathrm{A}}$ & 8.54 & $v_{\mathrm{A}}$ & 9 & $F_{\mathrm{A}}$ & 5.59 & 2.22 \\
\hline$Q_{\mathrm{B}}$ & 0.14 & $v_{\mathrm{B}}$ & 2 & $F_{\mathrm{B}}$ & 0.43 & 3.68 \\
\hline$Q_{\mathrm{AB}}$ & 0.63 & $v_{\mathrm{AB}}$ & 18 & $F_{\mathrm{AB}}$ & 0.20 & 1.87 \\
\hline$Q_{\varepsilon}$ & 20.3 & $v_{\varepsilon}$ & 120 & - & - & - \\
\hline
\end{tabular}

It should be noted that similar results were obtained for bushings of the type ГТБТУ-110, ГТТА-110, as well as for bushings of voltage class of 220 and $330 \mathrm{kV}$.
Analysis of the significance of differences of $\operatorname{tg} \delta_{1}$ values in serviceable high-voltage bushings with different classes of rated voltage. The normative document acting in Ukraine [1] provides the rationing of the values of diagnostic indicators depending on the rated voltage of the bushings, which implies the existence of significant differences in the values of the same indicator for the bushings of different voltage classes. To verify the presence of such differences, the dispersion analysis of $\operatorname{tg} \delta_{1}$ values was performed for bushings with paper-oil insulation of hermetic design with rated voltage of 110,220 and $330 \mathrm{kV}$. These bushings were commissioned in the early $90 \mathrm{~s}$ and operate with a load above $50 \%$ of the nominal current value. The volume of sample values was 108 values: 3 columns, 6 rows, 6 measurements per cell. The dividing step by factor of the duration of operation (in rows) was 4 years in the observation interval of up to 24 years. The dynamics of changes in the dielectric loss tangent of bushings of a hermetic design of voltage class of 110 , 220 and $330 \mathrm{kV}$ during operation is shown in Fig. 11.

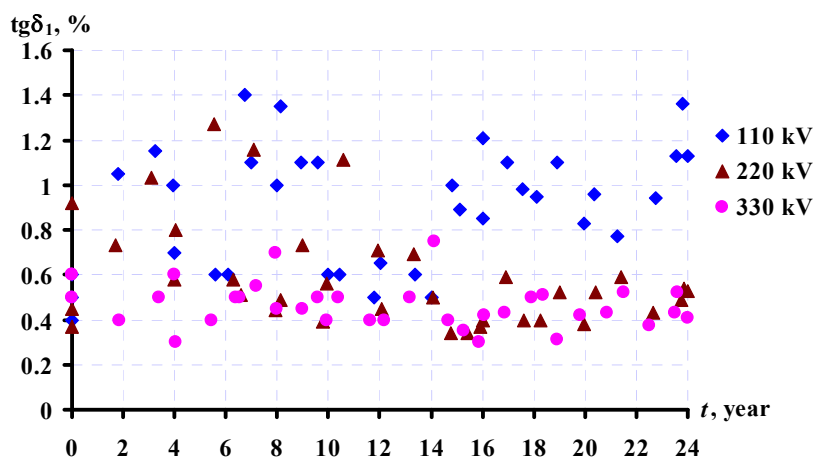

Fig. 11. Dynamics of changes in the dielectric loss tangent of bushings of a hermetic design of 110,220 and $330 \mathrm{kV}$ voltage classes during operation

The distribution of the average values of the tangent of the dielectric loss angle of the main insulation of highvoltage bushings, according to the levels of the influencing factors, is shown in Fig. 12.

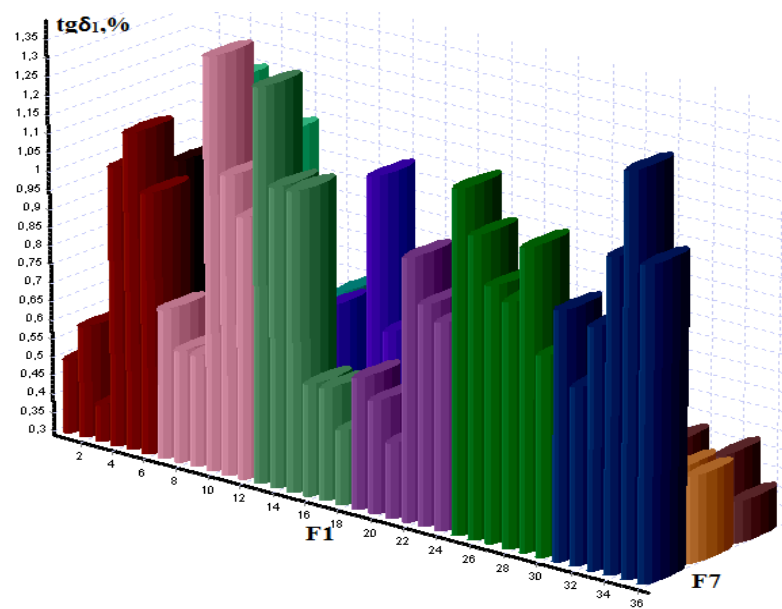

Fig. 12. The distribution of the average values of the tangent of dielectric loss of the main insulation of high-voltage bushings depending on the duration of operation (factor F1) and voltage class (factor F7) of high-voltage bushings 
The main hypothesis was the assumption that there are no significant effects of these factors. The results of the dispersion decomposition are given in Table 6 .

Table 6

The results of checking the influence of the duration of operation and the rated voltage of the bushings on the values of $\operatorname{tg} \delta_{1}$

\begin{tabular}{|c|c|c|c|c|c|c|}
\hline \multirow{2}{*}{\multicolumn{2}{|c|}{$\begin{array}{l}\text { Sums of dispersion } \\
\text { decomposition }\end{array}$}} & \multirow{2}{*}{\multicolumn{2}{|c|}{$\begin{array}{l}\text { Number of } \\
\text { degrees of } \\
\text { freedom }\end{array}$}} & \multicolumn{3}{|c|}{$F$-criterion } \\
\hline & & & & \multirow[t]{2}{*}{$F$} & \multirow[t]{2}{*}{ calculated } & \multirow[t]{2}{*}{ critical } \\
\hline$Q_{\text {tot. }}$ & 8.48 & $v_{\text {tot. }}$ & 107 & & & \\
\hline$Q_{\mathrm{A}}$ & 0.31 & $v_{\mathrm{A}}$ & 5 & $F_{\mathrm{A}}$ & 1.45 & 2.730 \\
\hline$Q_{\mathrm{B}}$ & 3.52 & $v_{\mathrm{B}}$ & 2 & $F_{\mathrm{B}}$ & 41.0 & 3.865 \\
\hline$Q_{\mathrm{AB}}$ & 0.78 & $v_{\mathrm{AB}}$ & 10 & $F_{\mathrm{AB}}$ & 1.83 & 2.213 \\
\hline$Q_{\varepsilon}$ & 3.86 & $v_{\varepsilon}$ & 90 & - & - & - \\
\hline
\end{tabular}

As can be seen from Table 6, the analysis performed revealed significant differences in the values of the tangent of dielectric loss of the main insulation of the bushings of different voltage classes $\left(F_{B}>F_{c r}\right)$.

But at the same time, a significant change over time of the $\operatorname{tg} \delta_{1}$ values for this sample was not established $\left(F_{A}<F_{c r}\right)$. There is also no significant difference in the values of $\operatorname{tg} \delta_{1}$, which is due to the mutual influence of the rated voltage of the bushings and the duration of their operation $\left(F_{A B}<F_{c r}\right)$.

Analysis of the significance of differences in $\operatorname{tg} \delta_{1}$ values in serviceable high-voltage bushings, which are operated in different regions of Ukraine. In some works, for example, [18], results are presented indicating that there is a significant influence of the region in which the equipment is operated on the values of diagnostic indicators. Such influence may be due to both different climatic conditions, and different composition of the consumer and, as a result, differences in the density of daily load schedules.

To check the influence of the region of Ukraine on the change in the values of diagnostic indicators of highvoltage bushings, an analysis of the values of $\operatorname{tg} \delta_{1}$ was performed for $110 \mathrm{kV}$ bushings of the hermetic design of type БMТ-110, which operate in Kharkiv, Lugansk and Poltava regions of Ukraine.

Taking into account that the bushings are approximately in the same climatic zone, the main factor influencing possible differences in the values of the dielectric loss tangent of the bushings will be the composition of consumers, and as a result, different density of daily load graphs. Analyzed bushings were put into operation in the late $70 \mathrm{~s}$ and operate with a load above $50 \%$ of the nominal value. The volume of sample values was 108 values: 3 columns, 6 rows, 6 measurements per cell. The dividing step by factor of the duration of operation (in rows) was 4 years in the observation interval of up to 24 years. The dynamics of changes in the dielectric loss tangent of high-voltage bushings from different regions of Ukraine in the process of operation is shown in Fig. 13.

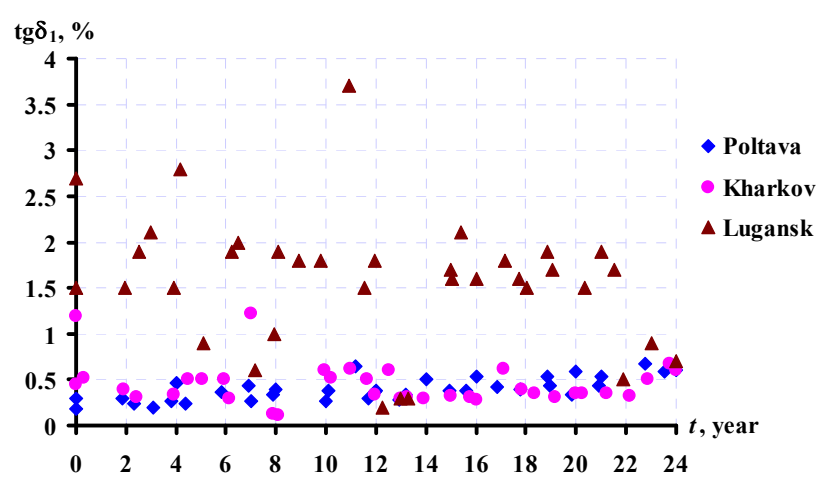

Fig. 13. Dynamics of changes in the dielectric loss tangent of high-voltage bushings from different regions of Ukraine during operation

The distribution of the average values of the tangent of the dielectric loss angle of the main insulation of highvoltage bushings by the levels of the influencing factors is shown in Fig. 14.

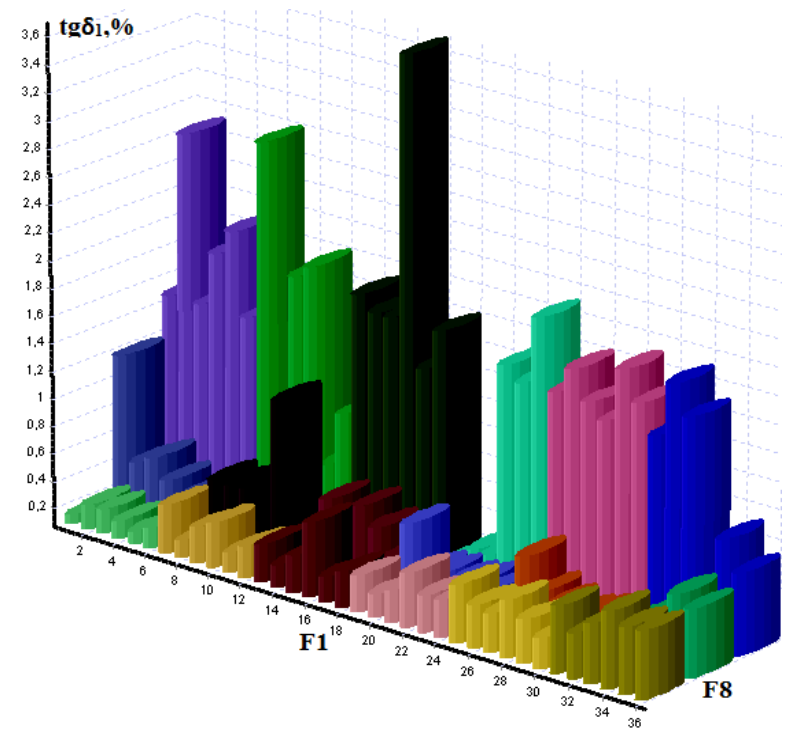

Fig. 14. The distribution of the average values of the tangent of dielectric loss of the main insulation depending on the duration of operation (factor F1) of high-voltage bushings and the region of Ukraine (factor F8)

The main hypothesis was the assumption that there are no significant effects of these factors. The results of the dispersion decomposition are given in Table 7. As can be seen from the Table 7 , for this sample, a significant change in the $\operatorname{tg} \delta_{1}$ values during operation was not established $\left(F_{A}<F_{c r}\right)$. But at the same time, significant differences were revealed in the values of $\operatorname{tg} \delta_{1}$ for bushings that are operated in different regions of Ukraine $\left(F_{B}>F_{c r}\right)$. As in the previous cases, there are no significant differences in the values of $\operatorname{tg} \delta_{1}$, due to the mutual influence of the region of Ukraine in which the bushings are operated, and the duration of their operation $\left(F_{A B}<F_{c r}\right)$. The conclusion about the significant effect of the density of the daily load schedule on the aging rate of the main insulation of the bushings was also confirmed for the bushings of the hermetic design of the type ГМТА -110 . 
Table 7

The results of checking the impact on the values of $\operatorname{tg} \delta_{1}$ of the duration of operation and the region of Ukraine

\begin{tabular}{|c|c|c|c|c|c|c|}
\hline \multirow{2}{*}{$\begin{array}{c}\text { Sums of dispersion } \\
\text { decomposition }\end{array}$} & \multicolumn{2}{|c|}{$\begin{array}{c}\text { Number of } \\
\text { degrees of } \\
\text { freedom }\end{array}$} & & \multicolumn{3}{|c|}{$F$-criterion } \\
\cline { 7 - 8 } & & & calculated & critical \\
\hline$Q_{\text {tot. }}$ & 51.90 & $v_{\text {tot. }}$ & 107 & & & \\
\hline$Q_{\mathrm{A}}$ & 1.54 & $v_{\mathrm{A}}$ & 5 & $F_{\mathrm{A}}$ & 1.81 & 2.73 \\
\hline$Q_{\mathrm{B}}$ & 31.39 & $v_{\mathrm{B}}$ & 2 & $F_{\mathrm{B}}$ & 92.5 & 3.86 \\
\hline$Q_{\mathrm{AB}}$ & 15.26 & $v_{\mathrm{AB}}$ & 10 & $F_{\mathrm{AB}}$ & 2.18 & 2.21 \\
\hline$Q_{\varepsilon}$ & 0.00 & $v_{\varepsilon}$ & 90 & - & - & - \\
\hline
\end{tabular}

As a result of the analysis performed, it was found that the aging rate of the main insulation of the bushings is significantly affected by both the operating conditions (the load current value of the bushings and the consumer's composition) and the design features of the bushings: the rated voltage value, type of insulation and type of protection of the bushings. Some of these factors, namely the rated voltage and the type of insulation, are taken into account in the regulatory document in force in Ukraine [1] when rationing the maximum permissible values of the indicators. At the same time, such factors as the value of the load current, the composition of the consumer and the type of protection are not taken into account when rationing the maximum permissible values of the indicators.

The results obtained above do not allow to unambiguously assess the presence or absence of the influence of the operating time on the values of $\operatorname{tg} \delta_{1}$. Of the seven examples given, the hypothesis of the absence of the influence of the duration of operation on the values of $\operatorname{tg} \delta_{1}$ was rejected only in three cases. It should be noted here that such discrepancies were revealed only for the factor of the duration of operation. For other factors when checking the hypothesis of the absence of their influence, the results obtained are identical for different samples. The revealed differences can be due both to the absence of influence of the duration of operation on the values of diagnostic indciators for serviceable bushings, and to the non-monotonic nature of the change in the values of $\operatorname{tg} \delta_{1}$ over time. The decision on the significance of the influence of the duration of operation on the values of diagnostic indicators of high-voltage bushings can be made after conducting additional studies, in particular, dispersion analysis of linear models of diagnostic indicators on the duration of operation.

\section{Conclusions.}

1. Maximum permissible values of diagnostic indicators of high-voltage bushings should be normalized taking into account such factors as rated voltage, type of protection and type of insulation, load of bushings and the composition of consumers, since, based on the analysis performed, it was established that these factors have a significant effect on the values of diagnostic indicators.

2. According to the results of the analysis, it was established that such factors as the bushing type and phase do not have a significant effect on the change in the values of diagnostic indicators of high-voltage bushings, and, therefore, they can be ignored when determining the maximum permissible values of the indicators.
3. The obtained results of the analysis did not confirm the recommendations from literature sources regarding the influence of some factors on the values of diagnostic indicators of bushings.

4. As further research, it is advisable to evaluate the effect of the operation time of the bushings on the values of their diagnostic indicators using other models of dispersion analysis. Here, it is of scientific and practical interest to carry out a similar assessment, both for serviceable bushings, and bushings with developing defects.

\section{REFERENCES}

1. SOU-N EE 20.302: 2007. Normy vyprobuvannja elektroobladnannja [Norms of testing of electrical equipment]. Kyiv, Ministry of Fuel and Energy of Ukraine, 262 p. (Ukr).

2. Shutenko O., Zagaynova A., Serdyukova G. Analysis of distribution laws of insulation indicators of high-voltage oilfilled bushings of hermetic and non-hermetic execution. Technology audit and production reserves, 2018, vol.4, no.1(42), pp. 30-39. doi: 10.15587/2312-8372.2018.140873.

3. Feilat E.A. Analysis of the Root Causes of Transformer Bushing Failures. International Journal of Computer, Electrical, Automation, Control and Information Engineering, 2013, vol.7, no.6, pp. 791-796

4. Anglhuber M., Juan L. Contreras Velásquez. Dispersing the clouds - gain clear insight into your bushings using advanced diagnostics method. Transformer Magazine. Special Edition: Bushing, 2017, pp. 126-132.

5. Septyani H.I., Arifianto I., Purnomoadi A.P. High voltage transformer bushing problems. Proceedings of the 2011 International Conference on Electrical Engineering and Informatics, Jul. 2011. doi: 10.1109/iceei.2011.6021566.

6. Metwally I. Failures, Monitoring and New Trends of Power Transformers. IEEE Potentials, 2011, vol.30, no.3, pp. 36-43. doi: 10.1109/mpot.2011.940233.

7. Rubanenko A.E., Gumenyuk A.I. Vysokovoltni vvody. Konstruktsiia, ekspluatatsiia, diahnostyka $i$ remont [Highvoltage bushings. Design, operation, diagnostics and repair]. Vinnitsa: VNTU Publ., 2011. 183 p. (Ukr).

8. IEC - 60137, Edition 7.0 2017-06. International Electrotechnical Commission Standard for Insulated bushings for alternating voltages above $1000 \mathrm{~V}$.

9. IEEE Std C57.19.01: Performance Characteristics and Dimensions for Outdoor Apparatus Bushings, 2000.

10. Andrienko P.D., Sakhno A.A., Konogray S.P., Spitsa A.G., Skrupskaya L.S. Features of monitoring the technical condition of the main insulation of high-voltage bushings and current transformers. Electrical engineering and power engineering, 2014, no.1, pp. 43-48. (Rus). doi: 10.15588/1607-6761-2014-1-7.

11. Anikeeva M.A., Arbuzov R.S., Zhivodernikov S.V., Lazareva E.A., Ovsyannikov A.G., Panov M.A. Diagnostic signs for rejection of high-voltage bushings with oil-paper insulation. ELEKTRO. Electrical engineering, power industry, electrical industry, 2009, no.1, pp. 22-25. (Rus).

12. Lvov M.Yu. Colloid-dispersed processes in high-voltage sealed bushings of transformers. Electric stations, 2000, no.4, pp. 49-52. (Rus).

13. Snetkova O.V. Experience of diagnostics of 110-500 kV oilfilled bushings in Mosenergo. ELEKTRO. Electrical engineering, power industry, electrical industry, 2004, no.2, pp. 39-42. (Rus).

14. Osotov V.N. Errors in measuring dielectric characteristics and assessing the state of high-voltage bushings. Proceedings 
of the 10th annual conference "Methods and means of insulation control of high-voltage equipment». Perm: Dimrus Publ., 2013. (Rus).

15. Zahaynova O.A. Analysis of the influence of different factors on the aging of the insulation capacitor type high-voltage input. Energy saving. Power engineering. Energy audit, 2015, no.10(141), pp. 17-25. (Rus).

16. Scheffe G. Dispersionnyi analiz [Dispersion analysis]. Moscow, Nauka Publ., 1980. 512 p. (Rus).

17. Johnson N. Statistika i planirovanie eksperimenta v tekhnike $i$ nauke [Statistics and Experiment Planning in Engineering and Science]. Moscow: Mir Publ., 1981. 520 p. (Rus).

18. Davidenko I.V. Investigation of indicators describing the operational state of oil-filled bushings, using mathematical statistics. University news. North-Caucasian region. Technical sciences series, 2006, no.15, pp. 31-33. (Rus).

19. Gmurman V.E. Teoriia veroiatnostei $i$ matematicheskaia statistika [Theory of Probability and Mathematical Statistics]. Moscow, High school Publ., 1977. 479 p. (Rus).

20. Shutenko O.V. Evaluation of the influence of operating conditions on the intensity of aging of transformer oils. Bulletin of NTU «KhPI», 2010, no.1. pp. 171-179. (Rus).

21. Shutenko O.V., Abramov V.B., Baklay D.N. Analysis of factors affecting the homogeneity of arrays of concentrations of gases dissolved in oil. Energetic and electrification, 2013, no.6, pp. 39-50. (Rus).
22. Davydenko A.P. Organizatsiia i planirovanie nauchnykh issledovanii, patentovedenie [Organization and planning of scientific research, patent science]. Kharkiv, NTU «KhPI» Publ., 2004. 320 p. (Rus).

23. Shutenko O.V., Baklay D.N. Planirovanie eksperimental'nykh issledovanii $v$ elektroenergetike. Metody obrabotki eksperimental'nykh dannykh [Planning of experimental research in the electric power industry. Methods for processing experimental data]. Kharkiv, NTU «KhPI» Publ., 2013. 268 p. (Rus).

24. Svi P.M. Kontrol' izoliatsii oborudovaniia vysokogo napriazheniia [Insulation control of high voltage equipment]. Moscow, Energoatomizdat Publ., 1988. 128 p. (Rus).

Received 25.10.2018

O.V. Shutenko ${ }^{1}$, Candidate of Technical Science, Associate Professor,

A.A. Zagaynova ${ }^{1}$, Assistant Lecturer,

G.N. Serdyukova ${ }^{1}$, Candidate of Technical Science, Associate Professor,

${ }^{1}$ National Technical University «Kharkiv Polytechnic Institute», 2, Kyrpychova Str., Kharkiv, 61002, Ukraine,

e-mail: o.v.shutenko@gmail.com, zagaynova@gmail.com, serdukova.galina@gmail.com.

How to cite this article:

Shutenko O.V., Zagaynova A.A., Serdyukova G.N. Analysis of operating conditions and modes influence on technical state of main insulation of high-voltage bushings of different design. Electrical engineering \& electromechanics, 2019, no.1, pp. 57-66. doi: 10.20998/2074-272X.2019.1.10. 